OPEN ACCESS

Edited by:

Pung P. Hwang,

Academia Sinica, Taiwan

Reviewed by:

Marian Yong-An Hu,

University of Kiel, Germany

Yung-Che Tseng,

Academia Sinica, Taiwan

*Correspondence:

Weiqun Lu

wqlv@shou.edu.cn

Youji Wang

youjiwang2@gmail.com

${ }^{\dagger}$ These authors have contributed equally to this work

Specialty section This article was submitted to

Aquatic Physiology,

a section of the journal

Frontiers in Physiology

Received: 29 October 2016 Accepted: 24 February 2017 Published: 09 March 2017

Citation:

Sui Y, Liu Y, Zhao X, Dupont S, Hu M,

Wu F, Huang $X$, Li J, LU W and Wang Y (2017) Defense Responses to

Short-term Hypoxia and Seawater Acidification in the Thick Shell Mussel Mytilus coruscus.

Front. Physiol. 8:145.

doi: 10.3389/fphys.2017.00145

\section{Defense Responses to Short-term Hypoxia and Seawater Acidification in the Thick Shell Mussel Mytilus coruscus}

\author{
Yanming Sui ${ }^{1,2+}$, Yimeng $\mathrm{Liu}^{1,3+}$, Xin Zhao ${ }^{2}$, Sam Dupont ${ }^{4}$, Menghong $\mathrm{Hu}^{1,3}$, Fangli Wu ${ }^{1}$, \\ Xizhi Huang ${ }^{1}$, Jiale $\mathrm{Li}^{1,3}$, Weiqun $\mathrm{Lu}^{1,3 *}$ and Youji Wang ${ }^{1,3 *}$ \\ ${ }^{1}$ Department of Biology, College of Fisheries and Life Science, Shanghai Ocean University, Shanghai, China, ${ }^{2}$ Key Laboratory \\ of East China Sea and Oceanic Fishery Resources Exploitation, Ministry of Agriculture of China, East China Sea Fisheries \\ Research Institute, Chinese Academy of Fisheries Sciences, Shanghai, China, ${ }^{3}$ Key Laboratory of Exploration and Utilization \\ of Aquatic Genetic Resources, Ministry of Education, Shanghai, China, ${ }^{4}$ Department of Biological and Environmental \\ Sciences, Sven Lovén Centre for Marine Sciences, University of Gothenburg, Fiskebäckskil, Sweden
}

The rising anthropogenic atmospheric $\mathrm{CO}_{2}$ results in the reduction of seawater $\mathrm{pH}$, namely ocean acidification (OA). In East China Sea, the largest coastal hypoxic zone was observed in the world. This region is also strongly impacted by ocean acidification as receiving much nutrient from Changjiang and Qiantangjiang, and organisms can experience great short-term natural variability of $\mathrm{DO}$ and $\mathrm{pH}$ in this area. In order to evaluate the defense responses of marine mussels under this scenario, the thick shell mussel Mytilus coruscus were exposed to three $\mathrm{pH} / \mathrm{pCO}_{2}$ levels $(7.3 / 2800 \mu \mathrm{atm}$, 7.7/1020 $\mu \mathrm{atm}, 8.1 / 376 \mu \mathrm{atm})$ at two dissolved oxygen concentrations (DO, 2.0, $6.0 \mathrm{mg} \mathrm{L}^{-1}$ ) for $72 \mathrm{~h}$. Results showed that byssus thread parameters, such as the number, diameter, attachment strength and plaque area were reduced by low DO, and shell-closing strength was significantly weaker under both hypoxia and low $\mathrm{pH}$ conditions. Expression patterns of genes related to mussel byssus protein (MBP) were affected by hypoxia. Generally, hypoxia reduced MBP1 and MBP7 expressions, but increased MBP13 expression. In conclusion, both hypoxia and low pH induced negative effects on mussel defense responses, with hypoxia being the main driver of change. In addition, significant interactive effects between $\mathrm{pH}$ and $\mathrm{DO}$ were observed on shell-closing strength. Therefore, the adverse effects induced by hypoxia on the defense of mussels may be aggravated by low pH in the natural environments.

Keywords: pH, hypoxia, byssus, mussel, defense response

\section{INTRODUCTION}

Anthropogenic $\mathrm{CO}_{2}$ emissions are driving increases in the net $\mathrm{CO}_{2}$ uptake by the oceans. Consequently, current average oceanic $\mathrm{pH}$ values are already 0.1 unit lower than pre-industrial values and are expected to decrease an extra $0.3-0.4$ unit by the end of 2,100 (Feely and Millero, 2004; Orr et al., 2005). Decreased $\mathrm{pH}$ results in profound modification of the seawater carbonate chemistry including a reduction of the calcite saturation state $\left[\Omega_{\mathrm{cal}}=\left(\left[\mathrm{Ca}^{2+}\right]\left[\mathrm{CO}_{3}^{2-}\right] / \mathrm{K}_{\mathrm{sp}}\right)\right.$, where $\mathrm{sp}$ is the solubility product at a assumed pressure, temperature and salinity]. This phenomenon 
is named "ocean acidification" (OA). At the same time, increasing global temperatures (global warming), closely related to changes in atmospheric $\mathrm{CO}_{2}$ concentrations, also lead to a more stratified surface ocean, cutting down exchange between deep and surface seawaters, resulting in expansion of oxygen-limited zones. Compared with colder waters, DO levels in warmer waters are lower, and global warming enhances the stratification of the upper ocean. These two factors decrease the supply of oxygen to the deeper parts of the ocean, spreading out hypoxic zones (Pörtner et al., 2005; Keeling et al., 2009; Feely et al., 2010; Stramma et al., 2010). Moreover, eutrophication usually exacerbates hypoxia in offshore waters (Levin et al., 2009).

In East China Sea, a $>12,000 \mathrm{~km}^{2}$ hypoxic zone was reported, comparable to the largest coastal hypoxic zones observed in the world (Chen et al., 2007). Such region is predicted to be also strongly impacted by ocean acidification (Cai et al., 2011; Chou et al., 2013; Melzner et al., 2013). Within this area, the Shengsi island is famous for its largest mussel aquaculture in China. This area is located at the river mouth of Changjiang and Qiantangjiang, and receives much nutrient, resulting in eutrophication and biological $\mathrm{CO}_{2}$ production, especially in wet season. Consequently, mussels can experience great natural variability of $\mathrm{DO}$ and $\mathrm{pH}$ in short-term (Chen et al., 2007; Li et al., 2014). Recently mass mussel mortalities frequently occurred in summer possibly due to short-term hypoxia or large $\mathrm{pH}$ fluctuation, for example, $\mathrm{DO}<3 \mathrm{mg} \mathrm{L}^{-1}$ and low $\mathrm{pH}$ 7.3-7.7 lasting for 3-7 days were found in our sampling area, the Shengsi island.

A growing number of studies has investigated the biological impact of hypoxia and ocean acidification, separately. OA has the potential to negatively impact marine organism (Melzner et al., 2009). For example, OA can decrease calcification rate (e.g., Kottmeier et al., 2016) and induce oxidative stress (e.g., Moolten, 2009). In the Akoya pearl oyster Pinctada fucata, calcification was proved to decrease due to OA (Liu et al., 2012). In addition, $\mathrm{CO}_{2}$ driven seawater acidification has been demonstrated to affect internal bicarbonate homeostasis, acid-base regulation as well as energy metabolism in many marine animals (Melzner et al., 2009; Hu et al., 2011, 2013, 2014a,b, 2016a,b; Stumpp et al., 2012a,b). The thick shell mussel Mytilus coruscus has been shown to produce more ROS under OA (Sui et al., 2016b). However, OA did not severely affect Mytilus galloprovincialis although reduced growth rates, lower acid-base regulation capacities and damage of the periostracum cover were found especially in summer when mussels are exposed to elevated temperature (Gazeau et al., 2014). Minor impacts of $\mathrm{OA}$ on growth and calcification were also observed in M. edulis, whereas food availability played a more important role in its tolerance to OA (Thomsen et al., 2013). In some areas of the Western Baltic Sea, seawater $\mathrm{pCO}_{2}$ can be high for prolonged periods due to upwelling of $\mathrm{CO}_{2}$ rich waters. Thomsen et al. (2010) showed that the blue mussel M. edulis from Kiel Fjord can maintain normal rates of somatic and shell growth at high $\mathrm{pCO}_{2}(1,400 \mu \mathrm{atm})$, indicating a potential pre-adaptation of Mytilus species to $\mathrm{pH}$ fluctuations. Low DO can occur naturally in estuaries, and the impacts of hypoxia on marine organism are also widely investigated (Keeling et al., 2009). Physiological responses to hypoxia are species specific (Pörtner et al., 2005; Seibel et al., 2014). For example, some bivalve species living in intertidal zone are tolerant to hypoxia because they are adaptive to variable habitats, whereas in other species (i.e., the target species Mytilus coruscus inhabits in subtidal zone) that are not regularly exposed to air, hypoxia can strongly impact their physiology, behaviors and distributions (Zhang et al., 2010; Wang et al., 2012). For example, hypoxia-inducible factors a (HIFa) and Hif-prolyl hydroxylases (PHD) proteins in the marine mussel Mytilus galloprovincialis were modulated by oxygen availability in a time-dependent manner with trends comparable to mRNA expression patterns (Giannetto et al., 2015).

A limited number of studies published to date have focused on the response to combined seawater hypoxia and acidification (Melzner et al., 2013; Gobler et al., 2014; Hernroth et al., 2015; Jakubowska and Normant, 2015; Sui et al., 2015). However, it is essential to understand the impacts of multiple stressors because these environmental changes do not change in isolation and their effects can be additive, synergistic or antagonistic (Breitburg et al., 2015). Gobler and Baumann (2016) reviewed the combined effects of $\mathrm{pH}$ and $\mathrm{DO}$ on the biological responses (e.g., survival, growth, metabolism) in numerous marine species. Additive negative effects seem to be the most common, but synergistic negative effects were also reported. To date, the interaction between $\mathrm{pH}$ and $\mathrm{DO}$ is poorly understood, and needs to be clarified.

Mytilus coruscus is a widely distributed mussel in coastal waters of the Yellow Sea and the East China Sea, and cultured as an important economic shellfish species, especially around the Shengsi island (Liao et al., 2013). This calcifier inhabits coastal ecosystem where it attaches to hard substrates in subtidal zones and forms large subtidal beds structuring the whole macrofauna communities. They attach to rocks under the water by byssal threads, preventing mussels from being removed and swept away by predators or waves. Additionally, the adductor muscle plays important behavioral functions such as opening and closing the shell, as well as being an energy reserve (Aoki et al., 2010). In general, healthy mussels close their valves tightly in response to various stimuli (e.g., wave and predator). Therefore, the strength of the adductor muscle and the byssus secretion ability in mussels reflect their defense level. In previous studies, we have investigated the energy budget and haemocyte responses of $M$. coruscus under simultaneous seawater acidification and hypoxia. We have shown that both stressors can negatively impact their physiology and immune response (Sui et al., 2016a,b). However, the mechanism and other aspects of the defense responses of mussels exposed to combined low $\mathrm{pH}$ and DO are still unclear.

In the present study, we evaluated strength of the adductor muscle and byssus performance of $M$. coruscus exposed to three $\mathrm{pH}$ values at two DO concentrations. The byssus consists of a thread, a flared adhesive plaque, and the plaque tip at the end of each thread that attaches to foreign surface. Byssus contains high concentrations of protein secreted by foot glands, among of which are mussel byssus proteins (MBP) 1,5, 7,13. MBP1 is only found in the plaque, MBP7 is only found in the thread, and both MBP5 and MBP13 are found in both the plaque and the thread (Sun et al., 2014). They are playing key roles in forming byssus. Hereby, gene expression patterns of mussel byssus proteins were 
also studied to better understand the defense mechanisms of $M$. coruscus exposed to low $\mathrm{pH}$ and DO.

\section{MATERIALS AND METHODS}

\section{Animal Collection}

Wild thick shell mussel $M$. coruscus (50 $\pm 6 \mathrm{~mm}$ shell length, $125.0 \pm 15.5 \mathrm{mg}$ dry tissue weight) were collected from a mussel raft at the Shengsi island in Zhejiang Province ( $30^{\circ} 33^{\prime} 00.945^{\prime \prime}$ $\left.\mathrm{N}, 121^{\circ} 49^{\prime} 59.757^{\prime \prime} \mathrm{E}\right)$, China. The handling of mussels was conducted according to the regulations of the animal welfare for scientific research made by the Institutional Animal Care and Use Committee (IACUC) of Shanghai Ocean University. These mussels were naturally growing in a fish farm and no specific permissions were required for collection or conducting our experiments. Mussels presenting no shell damage were selected and barnacles on the shells were gently removed. Mussels were first acclimated to laboratory conditions, mimicking the Shengsi island environment at the sampling time: temperature $20^{\circ} \mathrm{C}$, salinity 25.0, pH 8.1 and DO $6 \mathrm{mg} \mathrm{O}_{2} \mathrm{~L}^{-1}$ for 2 weeks in openflow tanks $(500 \mathrm{~L})$. They were fed twice daily with the microalgae Chlorella spp (algal strain from Shanghai Ocean University, 25,000 cells $\mathrm{mL}^{-1}$, ca. $3 \%$ of the mussel dry weight).

\section{Experimental Design and Seawater Chemistry}

$\mathrm{DO}$ and $\mathrm{pH}$ were tested in a fully crossed design: two DO levels $\left(2 \mathrm{mg} \mathrm{L} \mathrm{L}^{-1}\right.$ as hypoxic condition and $6 \mathrm{mg} \mathrm{L}^{-1}$ as normoxic condition); three $\mathrm{pH}$ levels ( $\mathrm{pH} 8.1$ as the present average $\mathrm{pH}, \mathrm{pH}$ 7.7 as the predicted average $\mathrm{pH}$ by the end of this century (IPCC, 2007) and extreme low value of the present natural variability in the sampling area (Li et al., 2014), and pH 7.3 as extreme low $\mathrm{pH}$ relevant for hypoxic zones by the year 2,100 (Cai et al., 2011). The experiment lasted for 3 days in triplicates for each treatment. In each replicate, 30 mussels were transferred to 30 perforated plastic containers $(100 \mathrm{~mL})$, and immerged into a $30 \mathrm{~L}$ tank.

DO was manipulated by injections of either $\mathrm{N}_{2}$ or air directly into the water via an $\mathrm{O}_{2}$ regulator (Loligo Systems Aps, Tjele, Denmark). The aquarium was sealed to prevent external disturbance. The $\mathrm{O}_{2}$ controller automatically allowed to maintain a stable $\mathrm{O}_{2}$ and $\mathrm{DO}$ level in each tank. The low $\mathrm{pH}$ was achieved by addition of pure $\mathrm{CO}_{2}$ using $\mathrm{pCO}_{2} / \mathrm{pH}$ feedback STAT systems (DAQ-M) connected to $\mathrm{pH}$ meters (WTW pH 3310) equipped with pH electrodes (SenTix 41) and operated by CapCTRL software (Loligo Systems Inc.). Salinity was regularly measured using a refractometer (S/Mill-E, Atago, Itabashi-Ku). Total alkalinity $\left(\mathrm{A}_{\mathrm{T}}\right)$ was measured by titration. Seawater carbonate chemistry parameters, including dissolved inorganic carbon (DIC), $\mathrm{pCO}_{2}$, saturation states of calcite $\left(\Omega_{\mathrm{ca}}\right)$ and aragonite $\left(\Omega_{\mathrm{ar}}\right)$ were calculated from $\mathrm{A}_{\mathrm{T}}$ and $\mathrm{pH}_{\mathrm{NBS}}$ using $\mathrm{CO}_{2}$ sys (Robbins et al., 2010) using $\mathrm{K} 1$ and $\mathrm{K} 2$ from Mehrbach et al. (1973) and refitted according to Millero (2010).

\section{Sample Collection for RNA Extraction and cDNA Synthesis}

To examine the expression of mussel byssus protein (MBP) genes during exposure to hypoxia and acidification, the foot gland was
TABLE 1 | Primers sequences of genes used in real-time PCR analysis.

\begin{tabular}{lll}
\hline Gene & Primer sequence $\left(\mathbf{5}^{\prime} \mathbf{- 3}^{\prime} \mathbf{)}\right.$ & GenBank accession number \\
\hline MBP-1-F & CCGTGTCAGTGTATCTCAACTC & G0898529.1 \\
MBP-1-R & CTCGGCAAGTAATCTGCTTAT & \\
MBP-5-F & GCATTTCACGGAGGAAGTAGAT & GR217715.1 \\
MBP-5-R & CCCGAATACGCTACACCATAAG & \\
MBP-7-F & TCTGGCCCATCGTCATATTAC & GR277545.1 \\
MBP-7-R & CACTCGCTGTGCAACTCTAT & \\
MBP-13-F & ATGTTGAGATCTTGGGATGT & GE759737.1 \\
MBP-13-R & CAGGATTGACCTGTCTGATGT & \\
$\beta$-actin-F & ATGAAACCACCTACAACAGT & GO898671.1 \\
$\beta$-actin-R & TAGACCCACCAATCCAGACG & \\
\hline
\end{tabular}

collected at $0,2,4,8,12,24,48$, and $72 \mathrm{~h}$. At each sampling time point, three mussels were randomly sampled from each replicate.

Total RNA was isolated from the foot gland using Trizol (Invitrogen, USA) following the manufacturer's protocol (Sun et al., 2014). The purity of the extracted RNA was determined by the OD260 $\mathrm{nm} / \mathrm{OD} 280 \mathrm{~nm}$ ratio, with expected values between 1.8 and 2.0. All of the RNA samples were treated with RNase free-DNase I (Takara, Japan) to remove residual genomic DNA before being reverse transcribed into cDNA using random hexamer primers and MMLV Reverse Transcriptase (Takara, Japan) according to the manufacturer's instructions.

\section{Quantitative Real-time PCR Analysis}

The quantitative real-time PCR (qRT-PCR) was carried out in 96-well qPCR plates by an ABI PRISM 7500 detector (Applied Biosystems, Foster City, CA). Specific primers for MBP1, MBP5, MBP7, MBP13 and $\beta$-actin transcripts were designed using the mussel $M$. coruscus foot gland mRNA sequences deposited in GenBank: MBP1 (GO898529.1), MBP5 (GR217715.1), MBP7 (GR277545.1), MBP13 (GE759737.1) and $\beta$-actin and Primer Premier 5.0. Primers used in this study were synthesized commercially (Sangon Biotech, Shanghai, China) (Table 1) and optimization and validation of primers for qRT-PCR were tested according to standard ABI protocols. qRT-PCR was carried out using NovoStart ${ }^{\circledR}$ SYBR qPCR SuperMix (NovoStart, Shanghai, China) according to manufacturer's instructions. For each sample, three reactions were conducted along with notemplate controls. qRT-PCR parameters were $95^{\circ} \mathrm{C}$, for $30 \mathrm{~s}$ followed by 40 cycles at $95^{\circ} \mathrm{C}$, for $5 \mathrm{~s}$, and $60^{\circ} \mathrm{C}$, for $34 \mathrm{~s}$. The gene expression levels were calculated using the comparative threshold cycle $(\mathrm{Ct})$ method and expressed as $2^{-\Delta \Delta \mathrm{Ct}}$ normalized to the $\beta$-actin gene expression (Liao et al., 2013; Liu et al., 2014, 2015).

\section{Measurement of Byssus Performance}

Byssus performance was assessed using methods adapted from a previous study (Wang et al., 2012). Three mussels from each tank were randomly selected after $72 \mathrm{~h}$, and four parameters were measured: (i) the number of byssus thread/byssus plaque; (ii) thread length using Vernier caliper (precision of $0.1 \mathrm{~mm}$ ); (iii) byssus thread diameter measured $1-1.5 \mathrm{~mm}$ from the adhesive 
TABLE 2 | Parameters of seawater carbonate chemistry during the experimental period $(n=3)$.

\begin{tabular}{|c|c|c|c|c|c|c|c|c|c|}
\hline $\begin{array}{l}\text { Treatments } \\
\mathrm{pH}{ }^{\star} \mathrm{DO}\end{array}$ & $\begin{array}{c}\text { DO } \\
\left(\mathrm{mg} \mathrm{L}^{-1}\right)\end{array}$ & $\begin{array}{c}\text { Temperature } \\
\left({ }^{\circ} \mathbf{C}\right)\end{array}$ & $\begin{array}{l}\text { Salinity } \\
\text { (psu) }\end{array}$ & $\mathrm{pH}_{\mathrm{NBS}}$ & $\begin{array}{c}\mathrm{A}_{\mathrm{T}} \\
\left(\mu \mathrm{mol} \mathrm{Kg}^{-1}\right)\end{array}$ & $\begin{array}{c}\text { DIC } \\
\left(\mu \mathrm{mol} \mathrm{Kg}^{-1}\right)\end{array}$ & $\begin{array}{c}\mathrm{pCO}_{2} \\
\text { ( } \mu \text { atm) }\end{array}$ & $\Omega c a$ & Rar \\
\hline $8.1^{\star} 2.0$ & $2.01 \pm 0.14$ & $20.0 \pm 0.2$ & $24.95 \pm 0.2$ & $8.11 \pm 0.01$ & $2299 \pm 21$ & $2072 \pm 13$ & $362 \pm 11$ & $4.47 \pm 0.10$ & $2.81 \pm 0.06$ \\
\hline $7.7^{\star} 2.0$ & $2.03 \pm 0.16$ & $20.1 \pm 0.3$ & $25.1 \pm 0.2$ & $7.73 \pm 0.02$ & $2311 \pm 26$ & $2228 \pm 15$ & $1005 \pm 20$ & $2.02 \pm 0.04$ & $1.27 \pm 0.03$ \\
\hline $7.3^{\star} 2.0$ & $2.04 \pm 0.13$ & $20.2 \pm 0.1$ & $25.2 \pm 0.4$ & $7.32 \pm 0.01$ & $2317 \pm 28$ & $2351 \pm 25$ & $2704 \pm 176$ & $0.83 \pm 0.03$ & $0.52 \pm 0.02$ \\
\hline $8.1^{\star} 6.0$ & $6.02 \pm 0.15$ & $20.1 \pm 0.3$ & $25.0 \pm 0.2$ & $8.11 \pm 0.01$ & $2304 \pm 4$ & $2073 \pm 14$ & $356 \pm 9$ & $4.54 \pm 0.10$ & $2.86 \pm 0.06$ \\
\hline $7.7^{\star} 6.0$ & $6.03 \pm 0.16$ & $20.2 \pm 0.2$ & $25.3 \pm 0.2$ & $7.71 \pm 0.01$ & $2312 \pm 26$ & $2224 \pm 15$ & $973 \pm 34$ & $2.08 \pm 0.06$ & $1.31 \pm 0.03$ \\
\hline $7.3^{\star} 6.0$ & $6.01 \pm 0.15$ & $20.1 \pm 0.1$ & $25.1 \pm 0.3$ & $7.27 \pm 0.02$ & $2325 \pm 10$ & $2348 \pm 27$ & $2681 \pm 212$ & $0.84 \pm 0.05$ & $0.53 \pm 0.03$ \\
\hline
\end{tabular}

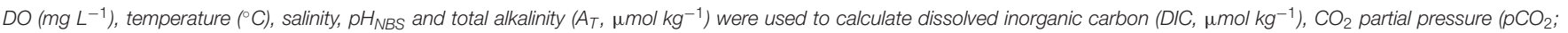
$\mu \mathrm{atm})$ and saturation states of aragonite ( $\Omega$ ar) and calcite ( $\Omega \mathrm{ca})$.

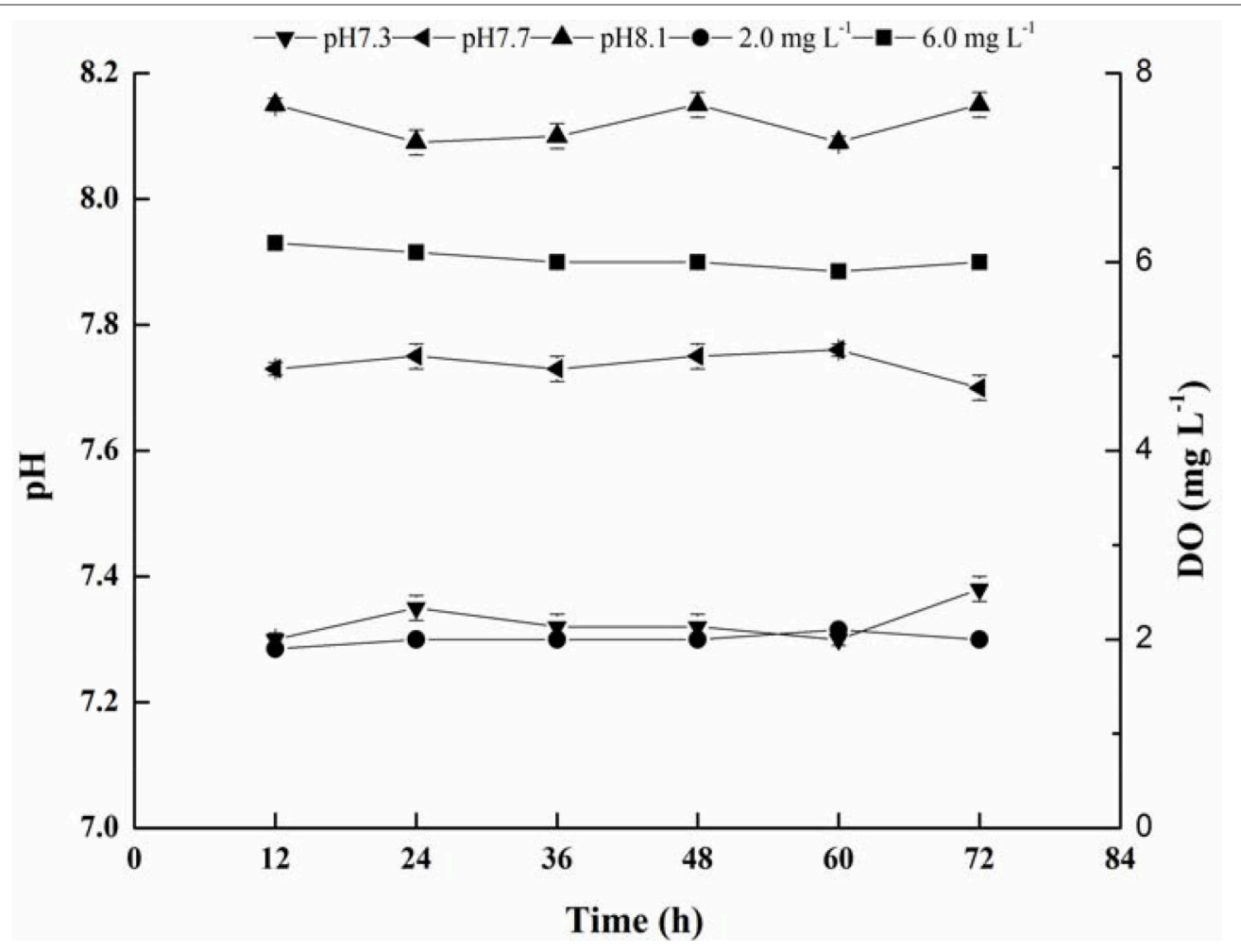

FIGURE 1 | Mean values of seawater $\mathrm{pH}$ and DO during the $72 \mathrm{~h}$ of exposure.

disk using a dissecting microscope equipped with an ocular micrometer (Nikon, precision of $0.01 \mathrm{~mm}$ ); and (iv) byssus plaque area examined under a light microscope and measured using an image analyzing software (Image J $1.43 \mathrm{u}$ ).

\section{Measurement of Byssus Attachment Strength}

Following a $72 \mathrm{~h}$ exposure to the different treatments, three mussels per tank were sampled and byssus strength was measured. Prior to measurement, the perforated plastic containers attached by byssus were scissored and fixed on a table, then the byssus attachment strength was evaluated using the method developed by Babarro and Comeau (2014) using a portable load meter (DPS-100R; Imada Co. Japan, precision of $0.1 \mathrm{~N})$.

\section{Measurement of Shell-closing Strength}

At the end of experiment, shell-closing strength (SCS) was also assessed on three mussels per tank. SCS is the load force required to open the shell of the mussel by $10 \mathrm{~mm}$ with a shell opener. The device for measuring shell-closing strength includes a portable load meter (DPS-100R; Imada Co. Japan, precision of $0.1 \mathrm{~N}$ ) and a shell opener (Nishii Co., Japan). To close the valves, the mussel was soaked in experimental water for $10 \mathrm{~min}$ before shell-closing strength measurement. Later, the shell opener was inserted into the crack between the valves, and the load force was determined. 
TABLE 3 | Summary of three-way ANOVA results on effects of pH, dissolved oxygen (DO) and time (T) on gene expressions of mussel byssus protein1, 5, 7, and 13 (MBP1, MBP5, MBP7, MBP13).

\begin{tabular}{|c|c|c|c|c|c|c|c|c|c|c|c|c|c|}
\hline Sources & df & \multicolumn{3}{|c|}{ MBP1 } & \multicolumn{3}{|c|}{ MBP5 } & \multicolumn{3}{|c|}{ MBP7 } & \multicolumn{3}{|c|}{ MBP13 } \\
\hline $\mathrm{pH}$ & 2 & 0.001 & 0.166 & 0.848 & 0.014 & 0.214 & 0.807 & 0.135 & 1.066 & 0.348 & 0.002 & 0.016 & 0.984 \\
\hline DO & 1 & 20.250 & 2438.739 & 0.000 & 0.000 & 0.004 & 0.948 & 304.997 & 2414.889 & 0.000 & 332.546 & 2236.551 & 0.000 \\
\hline $\mathrm{T}$ & 7 & 31.162 & 3752.935 & 0.000 & 22.369 & 348.518 & 0.000 & 415.032 & 3286.115 & 0.000 & 20.740 & 139.491 & 0.000 \\
\hline $\mathrm{pH}^{*} \mathrm{DO}$ & 2 & 0.001 & 0.145 & 0.865 & 0.012 & 0.185 & 0.832 & 0.108 & 0.852 & 0.430 & 0.000 & 0.001 & 0.999 \\
\hline $\mathrm{pH}^{*} \mathrm{DO} \mathrm{O}^{*} \mathrm{~T}$ & 14 & 0.000 & 0.052 & 1.000 & 0.001 & 0.010 & 1.000 & 0.067 & 0.533 & 0.908 & 0.001 & 0.008 & 1.000 \\
\hline
\end{tabular}

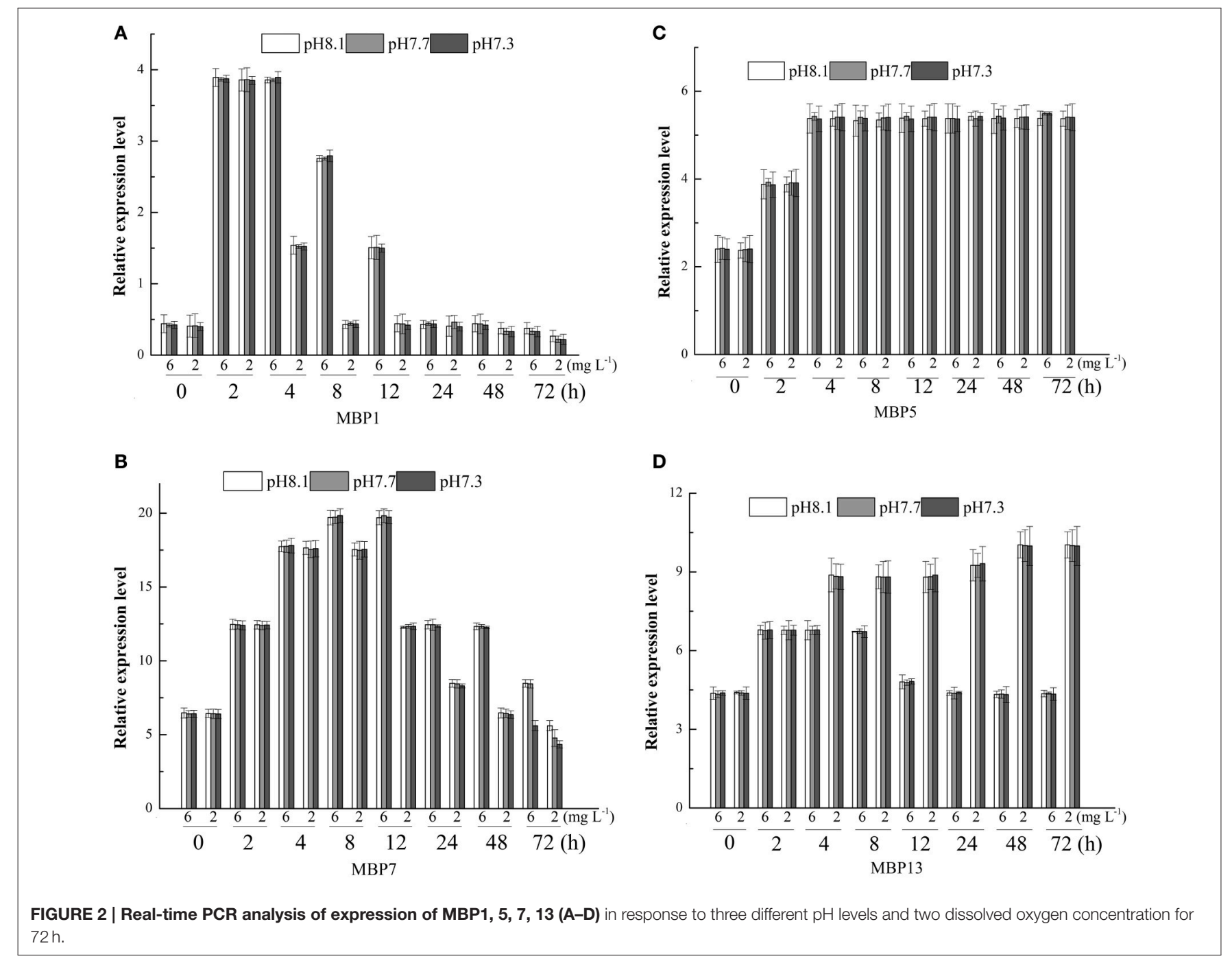

\section{Statistical Analysis}

Data were pooled in each tank, and individual tanks of each treatment were considered as replicates (i.e., $N=3$ ). Two-way ANOVAs were conducted to evaluate if $\mathrm{DO}, \mathrm{pH}$ and their interactions affected byssus performance and SCS. When the analysis showed significant interactions, a one-way
ANOVA was carried out for evaluating $\mathrm{pH}$ effects at each fixed DO level, followed by a Tukey's posteriori HSD test; student $t$-test was applied to test the difference between two DO groups at each fixed $\mathrm{pH}$ level, respectively. Threeway ANOVAs were used to evaluate whether time, DO, $\mathrm{pH}$ and their interactions affected genes expression. When 
TABLE 4 | Summary of two-way ANOVA results on effects of pH, and dissolved oxygen (DO) on byssus thread number (BTN), byssus thread diameter (BTD), byssus thread length (BTL), byssus attachment strength (BAS), byssus plaque area (BPA) and shell-closing strength (SCS) at the end of the experiment.

\begin{tabular}{|c|c|c|c|c|c|c|c|c|c|c|c|c|c|c|c|c|c|c|c|}
\hline \multirow[t]{2}{*}{ Sources } & \multirow[t]{2}{*}{ df } & \multicolumn{3}{|c|}{ BTN } & \multicolumn{3}{|c|}{ BTD } & \multicolumn{3}{|c|}{ BTL } & \multicolumn{3}{|c|}{ BAS } & \multicolumn{3}{|c|}{ BPA } & \multicolumn{3}{|c|}{ SCS } \\
\hline & & MS & $\mathbf{F}$ & $\mathbf{P}$ & MS & $\mathbf{F}$ & $\mathbf{P}$ & MS & $\mathbf{F}$ & $\mathbf{P}$ & MS & $\mathbf{F}$ & $\mathbf{P}$ & MS & $\mathbf{F}$ & $\mathbf{P}$ & MS & $\mathbf{F}$ & $\mathbf{P}$ \\
\hline DO & 2 & 34.72 & 13.587 & 0.003 & 0.000 & 6.738 & 0.023 & 0.006 & 0.013 & 0.910 & 30.42 & 13.727 & 0.003 & 0.001 & 0.411 & 0.533 & 4828.169 & 1931.697 & 0.000 \\
\hline $\mathrm{pH}$ & 1 & 1.722 & 0.674 & 0.528 & $6.572 \mathrm{E}-5$ & 0.963 & 0.410 & 0.427 & 0.945 & 0.416 & 0.932 & 0.42 & 0.666 & 0.000 & 0.137 & 0.873 & 24.855 & 9.944 & 0.003 \\
\hline $\mathrm{pH}^{\star} \mathrm{DO}$ & 2 & 0.056 & 0.022 & 0.979 & $1.372 \mathrm{E}-5$ & 0.201 & 0.821 & 0.016 & 0.036 & 0.965 & 0.052 & 0.023 & 0.977 & 6.667E-5 & 0.034 & 0.966 & 16.154 & 6.463 & 0.012 \\
\hline
\end{tabular}

interactions between the factors was found, the effect of each factor was analyzed independently at each level of the other factors by one-way ANOVA followed by Tukey's posteriori HSD test or student $t$ test and differences among treatments were considered significant when $\mathrm{p}$ was less than 0.05. The above analyses were carried out using SPSS18.0, and the values of all parameters are expressed as the means \pm S.D. Finally, Principal Component Analysis (PCA) was conducted by XLSTAT ${ }^{\circledR}$ 2014, and a biplot was graphed by integrating both the observations and the measured variables.

\section{RESULTS}

Seawater parameters ( $\mathrm{DO}$ and $\mathrm{pH}$ ) targets were achieved in all replicates. During the experiment, salinity was consistently kept at ca. $25 \%$, and DO concentrations were consistently kept at either $2 \mathrm{mg} \mathrm{L}^{-1}$ or $6 \mathrm{mg} \mathrm{L}^{-1}$ in the hypoxic and normoxic treatments, respectively., Total alkalinity was maintained at ca. $2,300 \mu \mathrm{mol} \mathrm{kg}{ }^{-1}$. The carbonate chemistry was also maintained at the desired levels (Table 2 and Figure 1).

The relative expression level of the gene associated with mussel byssus protein1 (MPB1) was significantly affected by DO, time and their interactions. There was no significant effect of $\mathrm{pH}$ on the relative expression level of this gene (Table 3). The relative expression level of MPB1 fluctuated largely during the experimental period and the relative expression level peaked at $2 \mathrm{~h}$ in both DO treatments (Figure 2A). During the first $2 \mathrm{~h}$, there were no significant differences between DO treatments. Between 4 and $12 \mathrm{~h}$, the gene expression levels in the DO $6.0 \mathrm{mg}$ $\mathrm{L}^{-1}$ group were significantly higher than in the DO $2.0 \mathrm{mg}$ $\mathrm{L}^{-1}$ treatments. At $24 \mathrm{~h}$, no significant differences were found between treatments. At $48 \mathrm{~h}$, although there were no significant differences between various $\mathrm{pH}$ groups when $\mathrm{DO}$ was $6.0 \mathrm{mg} \mathrm{L}^{-1}$. At DO $2.0 \mathrm{mg} \mathrm{L}^{-1}$, the gene expression level was significantly higher at $\mathrm{pH} 8.1$ as compared to $\mathrm{pH} 7.7$ and 7.3. At $72 \mathrm{~h}$, the gene expression level at $\mathrm{pH} 8.1$ group was significantly higher than $\mathrm{pH}$ 7.7 and 7.3 under both DO levels (Figure 2A).

The relative expression level of MBP5 was only significantly affected by time (Table 3). The relative expression level of MBP5 increased with time, peaked at $4 \mathrm{~h}$ and then maintained this level until the end of experiment (Figure 2B).

DO, time and their interaction showed significant effects on the relative expression level of MBP7 (Table 3). The peak of gene expression in the $6 \mathrm{mg} \mathrm{L}^{-1}$ treatment was observed at $8 \mathrm{~h}$ while the peak of expression was observed at $4 \mathrm{~h}$ in the $2 \mathrm{mg} \mathrm{L}^{-1}$ treatment (Figure 2C). From 8 to $48 \mathrm{~h}$, the gene expression level was significantly higher at $6 \mathrm{mg} \mathrm{L}^{-1}$ as compared to the $2 \mathrm{mg} \mathrm{L}^{-1}$ treatment. At $72 \mathrm{~h}$, the gene expression levels in the $6 \mathrm{mg} \mathrm{L}^{-1}$ treatment were significantly higher at $\mathrm{pH} 8.1$ and 7.7 as compared to $\mathrm{pH}$ 7.3. At $2 \mathrm{mg} \mathrm{L}^{-1}$, the gene expression level significantly decreased with $\mathrm{pH}$ reduction (Figure 2C).

The relative expression level of MBP13 was significantly affected by DO, time and their interaction (Table 3 ). In the $6 \mathrm{mg} \mathrm{L}^{-1}$ treatment, the relative expression level of MBP13 increased within $2 \mathrm{~h}$ and maintained at a high level until 12 $\mathrm{h}$, then it declined to the initial value at $48 \mathrm{~h}$. In the $2 \mathrm{mg}$ $\mathrm{L}^{-1}$ treatment, the relative expression level of MBP13 increased with time until $48 \mathrm{~h}$ and kept a high value until the end of the experiment (Figure 2D). During the first $2 \mathrm{~h}$, there were no significant differences between treatments. From 4 to $72 \mathrm{~h}$, the gene expression level in the $2 \mathrm{mg} \mathrm{L}^{-1}$ treatment was higher as compared to the $6 \mathrm{mg} \mathrm{L}^{-1}$ treatment (Figure 2D).

At the end of the experiment, significant effects of DO on the number of byssus threads, byssus threads diameter, byssus attachment strength were observed. There were no significant effects of $\mathrm{pH}$ and the interaction between $\mathrm{pH}$ and $\mathrm{DO}$ on these parameters (Table 4). DO, $\mathrm{pH}$, and their interaction did not show significant effects on byssus thread length and byssus plaque area (Table 4). The SCS was significant affected by $\mathrm{pH}, \mathrm{DO}$ and their interaction. Under normoxic conditions, SCS were significantly higher in $\mathrm{pH} 8.1$ and 7.7 as compared to $\mathrm{pH}$ 7.3.Under hypoxic conditions, there were no significant differences between $\mathrm{pH}$ treatments (Table 4, Figure 3).

PCA showed that $91.11 \%$ of total variance was explained by the two principal components (Figure 4). PC1 accounted for $75.32 \%$ of the total variance, and the most distinct response referred to the separation between the two DO treatments. PC2 explained $15.79 \%$ of the total variance, and separated low $\mathrm{pH} 7.3$ from the two other pHs (Figure 4).

\section{DISCUSSION}

M. coruscus could not only survive but also secret byssus under short-term hypoxia and low $\mathrm{pH}$ exposure. This suggests that this species is partly adapted to such short term fluctuations in $\mathrm{pH}$ and DO (Gobler et al., 2014). However, the shell-closing strength was weakened upon exposure to these conditions, showing that 

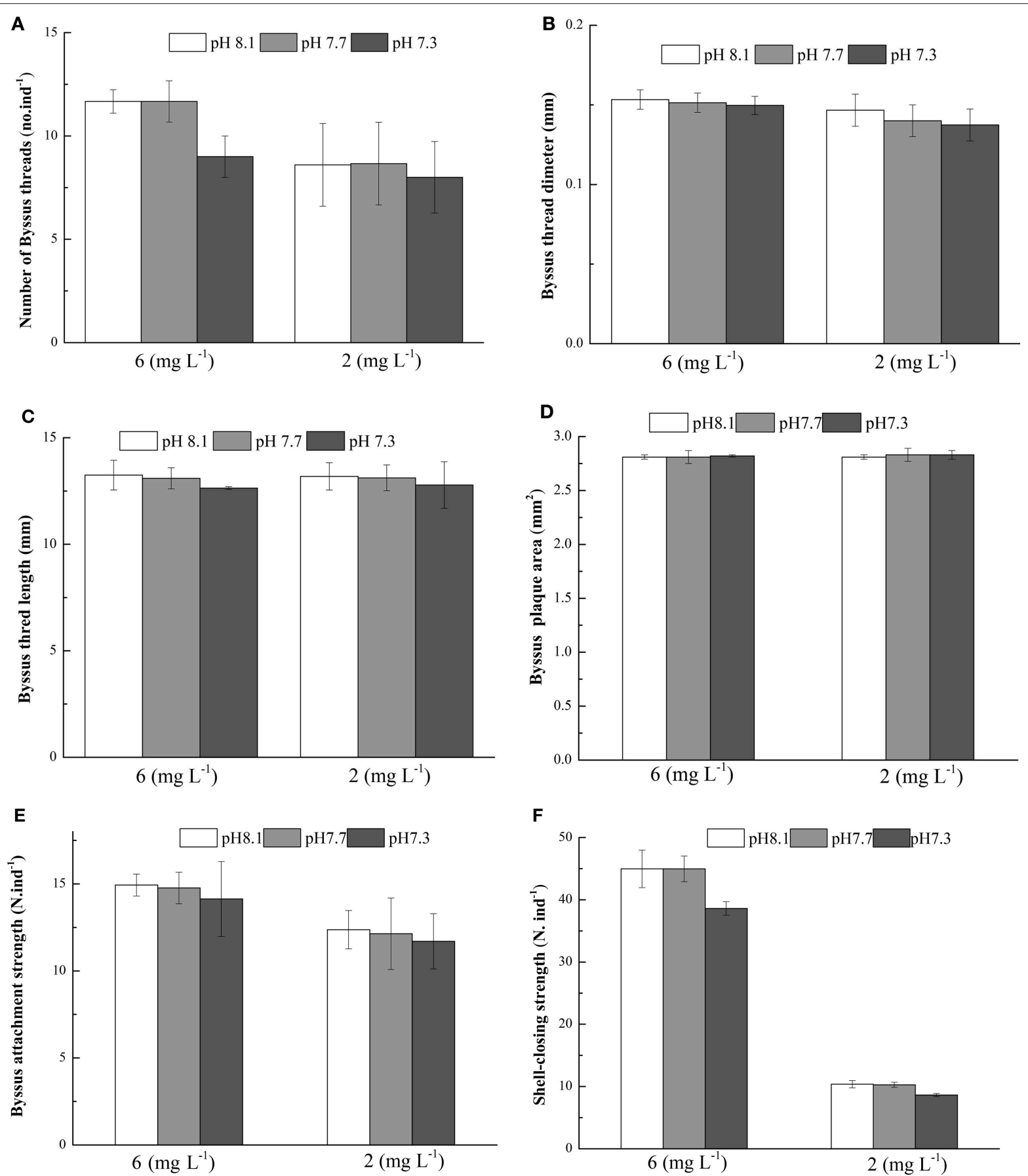

FIGURE 3 | Byssus thread number (A), Byssus threads diameter (B), Byssus thread length (C), Byssus plaque area (D), Byssus attachment strength (E) and Shell-closing strength (F) of $M$. coruscus exposed to three different $\mathrm{pH}$ levels and two dissolved oxygen concentration for $72 \mathrm{~h}$.

short term exposure to low $\mathrm{pH}$ and DO can impair the mussel's defense capacity.

The present study examined the changes of relative gene expressions of MBP1, MBP5, MBP7, and MBP13 associated with byssus secretion in the mussel $M$. coruscus under low $\mathrm{pH}$ and DO conditions. Among them, both MBP1 and MBP5 proteins have a collagen domain-containing protein (Qin et al.,
2016). Sun et al. (2014) speculated these collagen domaincontaining proteins might be crucial for the tenacity of byssus and probably participated in the cross-linking to mediate the interaction between the threads and plaque. The present study showed that DO was the driving factor influencing levels of mRNA transcript for MBP1\&7, whereas low $\mathrm{pH}$ aggravated the sensitivity of $M$. coruscus to hypoxia partly. In our previous 


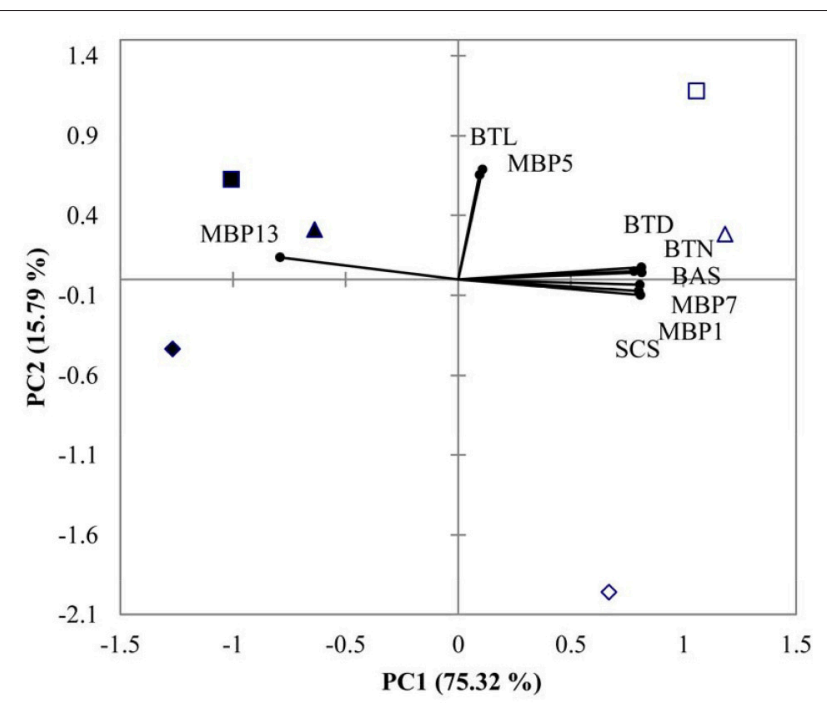

FIGURE 4 | PCA results of $M$. coruscus exposed to three different pH levels and two dissolved oxygen concentration at $72 \mathbf{h}$. $\left(\Delta 2 \mathrm{mg} \mathrm{L}^{-1} \times\right.$ $\mathrm{pH} 8.1, \Delta 6 \mathrm{mg} \mathrm{L}^{-1} \times \mathrm{pH} 8.1, \square 2 \mathrm{mg} \mathrm{L}^{-1} \times \mathrm{pH} 7.7, \square 6 \mathrm{mg} \mathrm{L}^{-1} \times \mathrm{pH} 7.7$, $2 \mathrm{mg} \mathrm{L}^{-1} \times \mathrm{pH} 7.3, \diamond 6 \mathrm{mg} \mathrm{L}^{-1} \times \mathrm{pH} 7.3$ ). Both the loadings of the variables $(\bullet)$ and the scores of the experimental conditions were shown. BTN, byssus thread number, BTD, byssus thread diameter, BTL, byssus thread length, BAS, byssus attachment strength, SCS, shell-closing strength and MBP, mussel byssus protein.

studies, hypoxia and low $\mathrm{pH}$ reduced the metabolic rate of $M$. coruscus (Wang et al., 2015; Sui et al., 2016a). Thus, reductions in mussel byssus protein expressions (i.e., MBP1\&7) under hypoxic conditions may be due to metabolic depression, and OA may aggravate such depression. Thomsen and Melzner (2010) observed increased energy expenditures and decreased $\mathrm{O}: \mathrm{N}$ ratios of $M$. edulis under increasing $\mathrm{pCO}_{2}$ conditions, indicating enhanced protein metabolisms. Thus, more energy may be allocated to intracellular $\mathrm{pH}$ regulation and protein synthesis may be reduced, resulting in a lower byssus production. MBP1 is only detected in plaque (Sun et al., 2014). As a consequence, the downregulation of the expression implied the seawater acidification and hypoxic may lead to a weakening of the formation of mussel plaque. The relative expression level of MBP5 was significantly affected by time only. This highlights the importance to consider multiple genes when studying the impact of seawater acidification and hypoxia. MBP7 is only identified in thread (Sun et al., 2014). This protein has a von Willebrand factor type A domains (VWA domains, Sun et al., 2014). The VWA domains is made of approximately 200 amino acid residues and is usually encountered in extracellular proteins (containing collagens, integrin, matrilin, complement factors) and mediated the adhesion via metal ion-dependent adhesion sites (Bork, 1991; Colombatti et al., 1993; Perkins et al., 1994). Accordingly, Sun et al. (2014) hypothesized that MBP7 would be a collagen-like, VWA domaining protein and could played an important role in the adhesion of byssus. In the present study, expression of MBP7 was significantly reduced after $8 \mathrm{~h}$ exposure to hypoxic conditions. This suggests that an exposure longer $8 \mathrm{~h}$ to hypoxia may have adverse effect on byssus thread formation.
MBP13 was identified in byssus plaque. It encodes a 181-aalong protein precursor, including a 17-aa-long signal peptide (Sun et al., 2014). There is a $\mathrm{Cu} / \mathrm{Zn}$ superoxide dismutaselike domain in the mature peptide of MBP13, which implied MBP13 could protect damages from reactive oxygen species by catalyzing the dismutation of superoxide into molecular oxygen and hydrogen peroxide (Schininà et al., 1985, 1989; Parge et al., 1992). Mussel adhesion depends on the process of DOPA oxidation and subsequent dopaquinone formation (Anderson et al., 2010). DOPA-rich byssus protein is mainly maintained in a reducing state before solidification outside substratum (Yu et al., 2011). The presences of superoxide dismutase domain in MBP13 could play a key role in redox balance to prevent premature oxidation of DOPA-rich protein (Sun et al., 2014). We found that the expression of MBP13 gene in hypoxic treatment was significantly higher than that in normoxic treatment after $4 \mathrm{~h}$ of exposure. This could suggest that mussels exposed to hypoxia need more MBP13 to eliminate the oxygen-mediated free radicals. This is supported by our previous observation that $M$. coruscus produced more oxygen-mediated free radicals when exposed to seawater acidification and hypoxia (Sui et al., 2016b).

Byssus production in mussels can be affected by many factors including temperature, $\mathrm{pH}$ ( $\mathrm{Li}$ et al., 2015), salinity (Wang et al., 2012) and current (Taylor et al., 1997). In our experiment, we showed that hypoxia weaken mussel byssus production. Under hypoxic conditions, byssus thread number, diameter, plaque area were significantly reduced. Similar results were reported in the green mussel $P$. viridis by Wang et al. (2012) who demonstrated that hypoxia resulted in a reduced number of byssus threads and thinner diameter. Similar results were also reported for the mussels Dreissena polymorpha (Clarke and McMahon, 1996) and M. edulis (Reish and Ayers, 1968). In our study, acidification had no effect on these parameters. This is only in partial agreement with the work on the pearl oysters $P$. fucata held at $\mathrm{pH} 7.8$ and $\mathrm{pH}$ 7.6. In this study, $\mathrm{pH}$ had no effect on the number of byssus threads, but byssus produced by that oysters were significantly thinner at 7.6 as compared to other $\mathrm{pH}$ treatments (Welladsen et al., 2011). Assuming that byssus production mirrors mussel adaptive capacity, it would mean that $M$. coruscus is less sensitive to $\mathrm{pH}$ changes than P. fucata.

Previous studies on bivalves showed that the high tensile strengths of byssus prevent them from being removed by wave action or predators (Steffani and Branch, 2003; Moeser et al., 2006; Dolmer and Svane, 2012). Seguin-Heine et al. (2014) reported that mussels maintained in more turbulent areas can produce more and stronger byssus compared to those in more sheltered environments. In the present experiment, hypoxia brought adverse effects on byssus attachment strength suggesting that hypoxia could weaken mussel defense capability.

Shell-closing strength is an important physiological indicator as healthy mussels generally keep their valves tightly closed in reaction to predators and waves (Aoki et al., 2010). Therefore, the shell-closing strength in mussels can mirror its defense performance. We showed that shell-closing strength was significantly affected by $\mathrm{DO}, \mathrm{pH}$ and their interaction. This suggests that seawater hypoxia and acidification has the potential to impair mussel defense capacity. More work is 
needed to better understand the interactive effect of the two drivers.

PCA allowed to discriminate normoxic treatments from hypoxic treatments by PC1. Normoxic treatments were associated with higher values of BTD, BTN, BAS, MPB7, MPB1, and SCS whereas hypoxia was associated with high MPB13. PC2 separated low $\mathrm{pH}$ (7.3) from higher $\mathrm{pH}$ (7.7 and 8.1) treatments (Figure 4). By integrating ANOVA and PCA results, the characteristics of the defense response to hypoxic exposure were lower BTD, BTN, BAS, MPB7, MPB1, and SCS associated with higher MPB1.

It is well documented that seawater acidification and hypoxia has the potential to harm many marine species (e.g., $\mathrm{Wu}$, 2002; Orr et al., 2005; Diaz and Rosenberg, 2008; Keppel et al., 2015; Wit et al., 2016). However, the interaction between these two drivers has received limited attention. This study stressed the importance of evaluating the combined effects of hypoxia and acidification on the defense responses in mussels. We showed that some aspects of the defense responses of $M$. coruscus was impaired by decreasing $\mathrm{DO}$ and $\mathrm{pH}$. Depressed byssus attachment strength and shell-closing strength may

\section{REFERENCES}

Anderson, T. H., Yu, J., Abril, E., Hammer, M. U., Herbert, W. J., and Israelachvili, J. N. (2010). The contribution of DOPA to substratepeptide adhesion and Internal cohesion of mussel-inspired synthetic peptide films. Adv. Funct. Mater. 20, 4196-4205. doi: 10.1002/adfm.201 000932

Aoki, H., Ishikawa, T., Fujiwara, T., Atsumi, T., Nishikawa, H., Okamoto, C., et al. (2010). Utility of shell-closing strength as the indicator of good health in breeding and culture management of Japanese pearl oyster Pinctada fucata. Aquaculture 308, S115-S118. doi: 10.1016/j.aquaculture.2010. 06.041

Babarro, J. M., and Comeau, L. A. (2014). Byssus attachment strength of two mytilids in mono-specific and mixed-species mussel beds. Biofouling 30, 975-985. doi: 10.1080/08927014.2014.953941

Bork, P. (1991). Shuffled domains in extracellular proteins. FEBS Lett. 286, 47-54. doi: 10.1016/0014-5793(91)80937-X

Breitburg, D. L., Salisbury, J., Bernhard, J. M., Cai, W. J., Dupont, S., Doney, S. C., et al. (2015). And on top of all that. coping with ocean acidification in the midst of many stressors. Oceanography 28, 48-61. doi: 10.5670/oceanog. 2015.31

Cai, W. J., Hu, X., Huang, W. J., Murrell, M. C., Lehrter, J. C., Lohrenz, S. E., et al. (2011). Acidification of subsurface coastal waters enhanced by eutrophication. Nat. Geosci. 4, 766-770. doi: 10.1038/ngeo1297

Chen, C.-C., Gong, G.-C., and Shiah, F.-K. (2007). Hypoxia in the East China sea: one of the largest coastal low-oxygen areas in the world. Mar. Environ. Res. 64, 399-408. doi: 10.1016/j.marenvres.2007.01.007

Chou, W. C., Gong, G. C., Cai, W. J., and Tseng, C. M. (2013). Seasonality of $\mathrm{CO}_{2}$ in coastal oceans altered by increasing anthropogenic nutrient delivery from large rivers: evidence from the Changjiang-East China sea system. Biogeosciences 10, 3889-3899. doi: 10.5194/bg-10-3889-2013

Clarke, M., and McMahon, R. F. (1996). Effects of hypoxia and lowfrequency agitation on byssogenesis in the freshwater mussel Dreissena polymorpha (Pallas). Biol. Bull. 191, 413-420. doi: 10.2307/15 43014

Colombatti, A., Bonaldo, P., and Doliana, R. (1993). Type a modules: interacting domains found in several non-fibrillar collagens and in other extracellular matrix proteins. Matrix 13, 297-306. doi: 10.1016/S0934-8832(11) 80025-9 enable predators and water current to remove mussels from the substrates more easily. Hence, $M$. coruscus would be more exposed to their predators under hypoxia and acidification in estuarine and coastal waters.

\section{AUTHOR CONTRIBUTIONS}

YW Designed and led the study, YS, YL, XZ, MH, and FW performed the experiments, YS, YL, XH, SD, JL, WL, and YW analyzed data and wrote the manuscript.

\section{ACKNOWLEDGMENTS}

This study was funded by research grants from Shanghai Municipal Natural Science Foundation (grant no. 17ZR1412900) and Natural Science Foundation of China (grant no. 31302207). This study was also supported by the open fund of Guangxi key laboratory of aquatic genetic breeding and healthy aquaculture. YW is supported by a fellowship from DAAD and China Scholarship Council. We also thank two reviewers for their constructive comments and suggestions.

Diaz, R. J., and Rosenberg, R. (2008). Spreading dead zones and consequences for marine ecosystems. Science 321, 926-929. doi: 10.1126/science.1 156401

Dolmer, P., and Svane, I. (2012). Attachment and orientation of Mytilus Edulis L. in flowing water. Ophelia 40, 63-74. doi: 10.1080/00785326.1994.104 29551

Feely, R. A., Alin, S. R., Newton, J., Sabine, C. L., Warner, M., Devol, A., et al. (2010). The combined effects of ocean acidification, mixing, and respiration on $\mathrm{pH}$ and carbonate saturation in an urbanized estuary. Estuarine Coast. Shelf Sci. 88, 442-449. doi: 10.1016/j.ecss.2010.05.004

Feely, R. A., and Millero, F. J. (2004). Impact of anthropogenic $\mathrm{CO}_{2}$ on the $\mathrm{CaCO}_{3}$ system in the oceans. Science 305, 362-366. doi: 10.1126/science.1097329

Gazeau, F., Alliouane, S., Bock, C., Bramanti, L., Correa, M. L., Gentile, M., et al. (2014). Impact of ocean acidification and warming on the Mediterranean mussel (Mytilus galloprovincialis). Front. Mar. Sci. 1:62. doi: $10.3389 /$ fmars.2014.00062

Giannetto, A., Maisano, M., Cappello, T., Oliva, S., Parrino, V., Natalotto. A., et al. (2015). Hypoxia-inducible factor $\alpha$ and Hif-prolyl hydroxylase characterization and gene expression in short-time air-exposed Mytilus galloprovincialis. Mar. Biotechnol.17, 768. doi: 10.1007/s10126-015-9655-7

Gobler, C. J., and Baumann, H. (2016). Hypoxia and acidification in ocean ecosystems: coupled dynamics and effects on marine life. Biol. Lett. 12:20150976. doi: 10.1098/rsbl.2015.0976

Gobler, C. J., DePasquale, E. L., Griffith, A. W., and Baumann, H. (2014). Hypoxia and acidification have additive and synergistic negative effects on the growth, survival, and metamorphosis of early life stage bivalves. PLOS ONE 9:e83648. doi: 10.1371/journal.pone.0083648

Hernroth, B., Krång, A. S., and Baden, S. (2015). Bacteriostatic suppression in Norway lobster (Nephrops norvegicus) exposed to manganese or hypoxia under pressure of ocean acidification. Aquat. Toxicol. 159, 217-224. doi: 10.1016/j.aquatox.2014.11.025

Hu, M. Y., Casties, I., Stumpp, M., Ortega-Martinez, O., and Dupont, S. (2014b). Energy metabolism and regeneration are impaired by seawater acidification in the infaunal brittlestar Amphiura filiformis. J. Exp. Biol. 217, 2411-2421. doi: 10.1242/jeb.100024

Hu, M. Y., Guh, Y. J., Shao, Y. T., Kuan, P. L., Chen, G. L., Lee, J. R. et al. (2016a). Strong ion regulatory abilities enable the crabXenograpsus testudinatusto inhabit highly acidified marine vent systems. Front. Physiol. 7:14. doi: 10.3389/fphys.2016.00014 
Hu, M. Y., Guh, Y. J., Stumpp, M., Lee, J. R., Chen, R. D., Sung, P. H., et al. (2014a). Branchial-dependent acid-base transport mechanisms and energy metabolism of squid (Sepioteuthis lessoniana) affected by seawater acidification.Front. Zool. 11:55. doi: 10.1186/s12983-014-0055-Z

Hu, M. Y., Lee, J. R., Lin, L. Y., Shih, T. H., Stumpp, M., Lee, M. F., et al. (2013). Development in a naturally acidified environment: $\mathrm{Na}^{+} / \mathrm{H}^{+}$-exchanger 3-based proton secretion leads to $\mathrm{CO}_{2}$ tolerance in cephalopod embryos. Front. Zool. 10:51. doi: 10.1186/1742-9994-10-51

Hu, M. Y., Michael, K., Kreiss, C. M., Stumpp, M., Dupont, S., Tseng, Y. C., et al. (2016b). Temperature modulates the effects of ocean acidification on intestinal ion transport in Atlantic cod,Gadus morhua.Front. Physiol. 7:198. doi: 10.3389/fphys.2016.00198

Hu, M. Y., Tseng, Y. C., Stumpp, M., Gutowska, M. A., Kiko, R., Lucassen, M., et al. (2011). Elevated seawater $\mathrm{PCO}_{2}$ differentially affects branchial acid-base transporters over the course of development in the cephalopod Sepia officinalis. Am. J. Physiol. 300, R1100-R1114. doi: 10.1152/ajpregu.00653.2010

IPCC (2007). "Climate change 2007: the physical science basis," in Contribution of Working Group I to the Fourth Assessment Report of the Intergovernmental Panel on Climate Change, eds S. Solomon, D. Qin, M. Manning, Z. Chen, M. Marquis, K. B. Averyt, M. Tignor, and H. L. Miller (Cambridge, UK: Cambridge University Press), 96

Jakubowska, M., and Normant, M. (2015). Metabolic rate and activity of blue mussel under short-term exposure to carbon dioxide-induced water acidification and oxygen deficiency. Mar. Behav. Physiol. 48, 25-39. doi: $10.1080 / 10236244.2014 .986865$

Keeling, R. E., Körtzinger, A., and Gruber, N. (2009). Ocean deoxygenation in a warming world. Annu. Rev. Mar. Sci. 2, 199-229. doi: 10.1146/annurev.marine.010908.163855

Keppel, A. G., Breitburg, D. L., Wikfors, G. H., Burrell, R. B., and Clark, V. M. (2015). Effects of co-varying diel-cycling hypoxia and $\mathrm{pH}$ on disease susceptibility in the eastern oyster Crassostrea virginica. Mar. Ecol. Prog. Ser. 538, 169-183. doi: 10.3354/meps11479

Kottmeier, D. M., Rokitta, S. D., and Rost, B. (2016). $\mathrm{H}^{+}$-driven increase in $\mathrm{CO}_{2}$ uptake and decrease in $\mathrm{HCO}^{-}$uptake explain coccolithophores' acclimation responses to ocean acidification. Limnol. Oceanogr. 61, 2045-2057. doi: 10.1002/lno. 10352

Levin, L. A., Ekau, W., Gooday, A. J., Jorissen, F., Middelburg, J. J., Naqvi, S. W. A., et al. (2009). Effects of natural and human-induced hypoxia on coastal benthos. Biogeosciences 6, 2063-2098. doi: 10.5194/bg-6-2063-2009

Li, H. M., Shi, X. Y., Chen, P., and Zhang, C. S. (2014). Effects of pH and DO on the migration and transformation of phosphate in the process of mixing in the Changjiang Estuary. Mar. Environ. Sci. 33, 497-502. Available online at: http:// www.cnki.com.cn/Article/CJFDTotal-HYHJ201404001.htm

Li, L. S., Lu, W. Q., Sui, Y. M., Wang, Y. J., Gul, Y., and Dupont, S. (2015). Conflicting effects of predator cue and ocean acidification on the mussel Mytilus coruscus byssus production. J. Shellfish Res. 34, 393-400. doi: 10.2983/035.034.0222

Liao, Z., Wang, X. C., Liu, H. H., Fan, M. H., Sun, J. J., and Shen, W. (2013). Molecular characterization of a novel antimicrobial peptide from Mytilus coruscus. Fish Shellfish Immunol. 34, 610-616. doi: 10.1016/j.fsi.2012.11.030

Liu, H., He, J., Zhao, R., Chi, C., and Bao, Y. (2015). A novel biomarker for marine environmental pollution of pi-class glutathione $\mathrm{S}$ transferase from Mytilus coruscus. Ecotoxicol. Environ. Saf. 118, 47-54. doi: 10.1016/j.ecoenv.2015.04.012

Liu, H. H., He, J. Y., Chi, C. F., and Shao, J. (2014). Differential HSP70 expression in Mytilus coruscus under various stressors. Gene 543, 166-173. doi: 10.1016/j.gene.2014.04.008

Liu, W., Huang, X., Lin, J., and He, M. (2012). Seawater acidification and elevated temperature affect gene expression patterns of the pearl oyster Pinctada fucata. PLos ONE 7:e33679. doi: 10.1371/journal.pone.0033679

Mehrbach, C., Culberson, C., Hawley, J., and Pytkowicx, R. (1973). Measurement of the apparent dissociation constants of carbonic acid in seawater at atmospheric pressure. Limnol. Oceanogr. 18, 897-907. doi: 10.4319/lo.1973.18.6.0897

Melzner, F., Gutowska, M. A., Langenbuch, M., Dupont, S., Lucassen, M., Thorndyke, M. C., et al. (2009). Physiological basis for high $\mathrm{CO}_{2}$ tolerance in marine ectothermic animals: pre-adaptation through lifestyle and ontogeny? Biogeosciences 6, 2313-2331. doi: 10.5194/bg-6-2313-2009
Melzner, F., Thomsen, J., Koeve, W., Oschlies, A., Gutowska, M. A., Bange, H. W., et al. (2013). Future ocean acidification will be amplified by hypoxia in coastal habitats. Mar. Biol. 160, 1875-1888. doi: 10.1007/s00227-0121954-1

Millero, F. J. (2010). Carbonate constants for estuarine waters. Mar. Freshw. Res. 61, 139-142. doi: 10.1071/MF09254

Moeser, G. M., Leba, H., and Carrington, E. (2006). Seasonal influence of wave action on thread production in Mytilus edulis. J. Exp. Biol. 209, 881-890. doi: $10.1242 /$ jeb.02050

Moolten, F. (2009). Ocean acidification: The other $\mathrm{CO}_{2}$ problem. Ann. Rev. Mar. Sci. 1, 169-192. doi: 10.1146/annurev.marine.010908.163834

Orr, J. C., Fabry, V. J., Aumont, O., Bopp, L., Doney, S. C., Feely, R. A., et al. (2005). Anthropogenic ocean acidification over the twenty-first century and its impact on calcifying organisms. Nature 437, 681-686. doi: 10.1038/nature04095

Parge, H. E., Hallewell, R. A., and Tainer, J. A. (1992). Atomic structures of wild-type and thermostable mutant recombinant human $\mathrm{Cu}, \mathrm{Zn}$ superoxide dismutase. Proc. Natl. Acad. Sci. U.S.A. 89, 6109-6113. doi: $10.1073 /$ pnas.89.13.6109

Perkins, S. J., Smith, K. F., Williams, S. C., Haris, P. I., Chapman, D., and Sim, R. B. (1994). The secondsary structure of the von Willebrand Factor type A domain in factor B of human complement by fourier transform infrared spectroscopy: its occurrence in collagen types VI, VII, XII and XIV, the integrins and other proteins by averaged structure pr. J. Mol. Biol. 238, 104-119. doi: $10.1006 /$ jmbi.1994.1271

Pörtner, H. O., Langenbuch, M., and Michaelidis, B. (2005). Synergistic effects of temperature extremes, hypoxia, and increases in $\mathrm{CO}_{2}$ on marine animals: from Earth history to global change. J. Geophys. Res. 110, 544-548. doi: 10.1029/2004JC002561

Qin, C. L., Pan, Q. D., Qi, Q., Fan, M. H., Sun, J. J., Li, N. N., et al. (2016). Indepth proteomic analysis of the byssus from marine mussel Mytilus coruscus. J. Proteomics 144, 87-98. doi: 10.1016/j.jprot.2016.06.014

Reish, D. J., and Ayers, J. L. (1968). Studies on the Mytilus edulis community in Alamitos Bay, California. III. The effects of reduced dissolved oxygen and chlorinity concentrations on survival and byssal thread production. Veliger 184, 357-360.

Robbins, L. L., Hansen, M. E., Kleypas, J. A., and Meylan, S. C. (2010). CO2calc: A User-friendly Seawater Carbon Calculator for Windows, Mac OS X, and iOS (iPhone). Open-File Report.

Schininà, M. E., Barra, D., Bossa, F., Calabrese, L., Montesano, L., Carrì, M. T., et al. (1989). Primary structure from amino acid and cDNA sequences of two $\mathrm{Cu}, \mathrm{Zn}$ superoxide dismutase variants from Xenopus laevis is. Arch. Biochem. Biophys. 272, 507-515. doi: 10.1016/0003-9861(89)90246-4

Schininà, M. E., Barra, D., Simmaco, M., Bossa, F., and Rotilio, G. (1985). Primary structure of porcine $\mathrm{Cu}, \mathrm{Zn}$ Superoxide dismutase. FEBS Lett. 186, 267-270. doi: 10.1016/0014-5793(85)80722-5

Seguin-Heine, M. O., Lachance, A. A., Genard, B., Myrand, B., Pellerin, C., Marcotte, I., et al. (2014). Impact of open sea habitat on byssus attachment of suspension-cultured blue mussels (Mytilus edulis). Aquaculture 426-427, 189-196. doi: 10.1016/j.aquaculture.2014.02.006

Seibel, B. A., Häfker, N. S., Trübenbach, K., Zhang, J., Tessier, S. N., Pörtner, H. O., et al. (2014). Metabolic suppression during protracted exposure to hypoxia in the jumbo squid, Dosidicus gigas, living in an oxygen minimum zone. J. Exp. Biol. 217, 2555-2568. doi: 10.1242/jeb.100487

Steffani, C. N., and Branch, G. M. (2003). Growth rate, condition, and shell shape of Mytilus galloprovincialis: responses to wave exposure. Mar. Ecol. Prog. Ser. 246, 197-209. doi: 10.3354/meps246197

Stramma, L., Schmidtko, S., Levin, L. A., and Johnson, G. C. (2010). Ocean oxygen minima expansions and their biological impacts. Deep Sea Res. Part I. 57, 587-595. doi: 10.1016/j.dsr.2010.01.005

Stumpp, M., Hu, M. Y., Melzner, F., Gutowska, M. A., Dorey, N., Himmerkus, N., et al. (2012b). Acidified seawater impacts sea urchin larvae $\mathrm{pH}$ regulatory systems relevant for calcification.Proc. Nat. Acad. Sci. U.S.A. 109, 18192-18197. doi: 10.1073/pnas.1209174109

Stumpp, M., Trübenbach, K., Brennecke, D., Hu, M. Y., and Melzner, F. (2012a). Resource allocation and extracellular acid-base status in the sea urchin Strongylocentrotus droebachiensis in response to $\mathrm{CO}_{2}$ induced seawater acidification. Aquat. Toxicol. 110-111, 194-207. doi: 10.1016/j.aquatox.2011.12.020 
Sui, Y., Hu, M., Huang, X., Wang, Y., and Lu, W. (2015). Anti-predatory responses of the thick shell mussel Mytilus coruscus exposed to seawater acidification and hypoxia. Mar. Environ. Res. 109, 159-167. doi: 10.1016/j.marenvres.2015.07.008

Sui, Y., Kong, H., Huang, X., Dupont, S., Hu, M., Storch, D., et al. (2016a). Combined effects of short-term exposure to elevated $\mathrm{CO}_{2}$ and decreased $\mathrm{O}_{2}$ on the physiology and energy budget of the thick shell mussel Mytilus coruscus. Chemosphere 155, 207-216. doi: 10.1016/j.chemosphere.2016.04.054

Sui, Y., Kong, H., Shang, Y., Huang, X., Wu, F., Hu, M., et al. (2016b). Effects of short-term hypoxia and seawater acidification on hemocyte responses of the mussel Mytilus coruscus. Mar. Pollut. Bull. 108, 46-52. doi: 10.1016/j.marpolbul.2016.05.001

Sun, J.-J., Nan-Nan, L. I., Wang, X.-C., and Liao, Z. (2014). Characterization of novel byssal proteins from Mytilus coruscus by shotgun mass spectrometry. Chin. J. Biochem. Mol. Biol. 30, 75-84. Available online at: http://cjbmb.bjmu. edu.cn/EN/Y2014/V30/I1/75

Taylor, J. J., Rose, R. A., and Southgate, P. C. (1997). Byssus production in six age classes of the silver-lip Pearl oyster, Pinctada maxima (Jameson). J. Shellfish Res. $16,97-101$.

Thomsen, J., Casties, I., Pansch, C., Körtzinger, A., and Melzner, F. (2013). Food availability outweighs ocean acidification effects in juvenile Mytilus edulis: laboratory and field experiments. Glob. Change Biol. 19, 1017-1027. doi: $10.1111 /$ gcb.12109

Thomsen, J., Gutowska, M. A., Saphörster, J., Heinemann, A., Trübenbach, K., Fietzke, J., et al. (2010). Calcifying invertebrates succeed in a naturally $\mathrm{CO}_{2}$ rich coastal habitat but are threatened by high levels of future acidification. Biogeosciences 7, 3879-3891. doi: 10.5194/bg-7-3879-2010

Thomsen, J., and Melzner, F. (2010). Moderate seawater acidification does not elicit long-term metabolic depression in the blue mussel Mytilus edulis. Mar. Biol. 157, 2667-2676. doi: 10.1007/s00227-010-1527-0

Wang, Y., Hu, M., Cheung, S. G., Shin, P. K. S., Lu, W., and Li, J. (2012). Chronic hypoxia and low salinity impair anti-predatory responses of the green-lipped mussel Perna viridis. Mar. Environ. Res. 77, 84-89. doi: 10.1016/j.marenvres.2012.02.006

Wang, Y. J., Li, L. S., Hu, M. H., and Lu, W. Q. (2015). Physiological energetics of the thick shell mussel Mytilus coruscus exposed to seawater acidification and thermal stress. Sci. Total Environ. 514, 261-272. doi: 10.1016/j.scitotenv.2015.01.092

Welladsen, H. M., Heimann, K., and Southgate, P. C. (2011). The effects of exposure to near-future levels of ocean acidification on activity and byssus production of the Akoya pearl oyster, Pinctada fucata. J. Shellfish Res. 30, 85-88. doi: 10.2983/035.030.0112

Wit, J. C., Davis, M. M., McCorkle, D. C., and Bernhard, J. M. (2016). A shortterm survival experiment assessing impacts of ocean acidification and hypoxia on the benthic foraminifer Globobulimina turgida. J. Foramin. Res. 46, 25-33. doi: 10.2113 /gsifr.46.1.25

Wu, R. S. S. (2002). Hypoxia: from molecular responses to ecosystem responses. Mar. Pollut. Bull. 45, 35-45. doi: 10.1016/S0025-326X(02)00061-9

Yu, J., Wei, W., Danner, E., Ashley, R. K., Israelachvili, J. N., and Waite, J. H. (2011). Mussel protein adhesion depends on interprotein thiolmediated redox modulation. Nat. Chem. Biol. 7, 588-590. doi: 10.1038/ nchembio. 630

Zhang, J., Gilbert, D., Gooday, A. J., Levin, L., Naqvi, S. W. A., Middelburg, J. J., et al. (2010). Natural and human-induced hypoxia and consequences for coastal areas: synthesis and future development. Biogeosciences 7, 1443-1467. doi: 10.5194/bg-7-1443-2010

Conflict of Interest Statement: The authors declare that the research was conducted in the absence of any commercial or financial relationships that could be construed as a potential conflict of interest.

The reviewer YT and handling Editor declared their shared affiliation, and the handling Editor states that the process nevertheless met the standards of a fair and objective review.

Copyright (c) 2017 Sui, Liu, Zhao, Dupont, Hu, Wu, Huang, Li, Lu and Wang. This is an open-access article distributed under the terms of the Creative Commons Attribution License (CC BY). The use, distribution or reproduction in other forums is permitted, provided the original author(s) or licensor are credited and that the original publication in this journal is cited, in accordance with accepted academic practice. No use, distribution or reproduction is permitted which does not comply with these terms. 